PRACE GEOGRAFICZNE

zeszyt 150, 2017, 41-59

doi: 10.4467/20833113PG.17.016.7320

Instytut Geografii i Gospodarki Przestrzennej UJ

Wydawnictwo Uniwersytetu Jagiellońskiego

\title{
TRANSFORMACJA UKŁADU KORYTOWEGO DOLNEJ SKAWY
}

\author{
Karol Witkowski
}

\section{Transformation of the lower Skawa River channel pattern}

Abstract: The present-day channel patterns of Carpathian rivers are a result of intensified human activity, which mainly involved narrowing of channels and setting regulatory routes. The processes of erosion and redeposition, that intensify with high water levels, often lead to the creation of certain sections in the river channel, which divert from the single channel pattern arrangement stabilized by man. The aim of this work is to establish the scale, source and direction of transformations of the lower Skawa river channel in the period between the $19^{\text {th }}$ and the $21^{\text {st }}$ century. With the establishment of the factors involved in the transformation of a braided channel existing in the $19^{\text {th }}$ century into a single channel in the $20^{\text {th }}$ century, we are able to identify the determinants in the segmental renaturalisation of the currently existing river channel. Our analysis was based on cartographic materials, which allowed for the comparison of the river channel in the $19^{\text {th }}$ and the $20^{\text {th }}$ century. The basic source with regard to the former period was the second military mapping survey of Austria-Hungary created in the years 1806-1896. As a representation of the current channel state we used a Google Satellite photo from 2012. The results of measurements preformed on the cartographic materials were used as input data in the process of classification of the channel pattern and mid-channel formations. The Skawa river channel was classified using the method developed by Brice (1975). The analysis led to a conclusion that the change of the Skawa river channel pattern was a result of its adjustment. The present-day river channel develops braided channel segments in places where the regulatory route has been damaged.

Keywords: morphometry, channel pattern, channel typology 
Zarys treści: Współczesne układy korytowe rzek karpackich powstały na skutek nasilonej antropopresji, sprowadzającej się przede wszystkim do zawężania łożysk i wytyczenia tras regulacyjnych. Intensyfikujące się w czasie wezbrań procesy erozji i redepozycji częstokroć prowadzą do powstania odcinków koryta, które w swym układzie odbiegają od jednonurtowego kanału ustabilizowanego przez człowieka. Celem opracowania jest określenie skali, genezy i kierunku przekształceń układu korytowego dolnej Skawy w XIX-XXI w. Uchwycenie czynników transformacji XIX-wiecznego koryta wielonurtowego w XX-wieczne koryto jednonurtowe, pozwala na rozpoznanie uwarunkowań odcinkowej renaturyzacji współczesnego koryta. Podstawą analiz były materiały kartograficzne umożliwiające porównanie koryta XIX i XXI-wiecznego. Bazowym źródłem była mapa drugiego wojskowego zdjęcia Austro-Węgier (tzw. zdjęcia franciszkowskiego), wykonana w latach 1806-1869. Jako materiał obrazujący współczesne koryto wykorzystano obraz satelitarny Google Satellite z 2012 r. Wyniki pomiarów na materiałach kartograficznych posłużyły jako dane wejściowe do przeprowadzenia klasyfikacji układu korytowego oraz form śródkorytowych. Klasyfikację koryta Skawy wykonano wg metody Brice'a (1975). Na podstawie analiz stwierdzono, iż do zmiany układu korytowego Skawy doszło na skutek regulacji koryta. We współczesnym korycie, w miejscach, gdzie dochodzi do zniszczenia trasy regulacyjnej, rozwijają się odcinki wielonurtowe.

Stowa kluczowe: układ korytowy, klasyfikacja rzek, morfometria

\section{Wprowadzenie}

Naturalne transformacje układów korytowych są procesami długotrwałymi (Teisseyre 1991). Działalność człowieka, tak jak wezbrania o wysokim natężeniu przepływu, może prowadzić do lokalnych przekształceń rzeźby dna doliny, znacznie przyspieszając proces transformacji układu korytowego (Klimek 1987). Współczesne układy korytowe rzek karpackich powstały na skutek nasilonej antropopresji, sprowadzającej się przede wszystkim do zawężania XIX-wiecznych koryt i wytyczania tras regulacyjnych. Wpływ ten udokumentowano na wielu odcinkach rzek, m.in. na Rabie (Wyżga 1993), Dunajcu (Zawiejska, Wyżga 2010), Sole (Woskowicz-Ślęzak, Ślęzak 2012) i Skawie (Witkowski 2015a). Zmiany użytkowania terenów w zlewniach, prowadzące do zmniejszania powierzchni gruntów ornych, sprzyjały stabilizowaniu jednonurtowych układów korytowych (Lach, Wyżga 2002; Wyżga i in. 2013).

Intensyfikujące się w czasie wezbrań procesy erozji, redepozycji i transportu częstokroć prowadzą do powstania odcinków koryta, które w swym układzie odbiegają od jednonurtowego kanału, ustabilizowanego przez człowieka (Zwoliński 1992). W przypadku doliny Skawy związana z niszczeniem umocnionych brzegów okresowa renaturyzacja koryta, wykształca odcinki wielonurtowe (Witkowski 2015a), których lokalizacja jest zbieżna z położeniem koryt rozgałęzionych w XIX w. 


\section{Charakterystyka fizycznogeograficzna doliny dolnej Skawy}

Skawa jest jednym z karpackich dopływów Wisły, odwadniającym Beskidy wraz z najwyższymi partiami Beskidów Zachodnich, masywem Babiej Góry (1725 m n.p.m.) - oraz pogórza. Ujściowy odcinek rzeki znajduje się w dolinie Wisły, na obszarze Kotliny Oświęcimskiej. Położenie zlewni Skawy determinuje jej cechy fizycznogeograficzne, a co za tym idzie, podział biegu rzeki na górny - beskidzki, i dolny - pogórski. W turystycznym podziale doliny dyktowanym uproszczonym podejściem granicę postawiono u progu Beskidu Małego w Wadowicach. Hydrologiczny opis doliny Skawy (Charakterystyka obszaru działania, http://oki.krakow. rzgw.gov.pl) stawia granicę górnej i dolnej Skawy w ujściu Stryszówki, niewielkiego, prawobrzeżnego dopływu Skawy. Bliska zakończenia budowa wielofunkcyjnego zbiornika wodnego w Świnnej Porębie skłania jednak do rewizji tych podziałów. Na długości ok. 10 km, od Świnnej Poręby, w górę Skawy, rozciągać się będzie zbiornik, w którego jednej z zatok będzie się znajdować ujście Stryszówki. Właściwym, nowym miejscem, rozgraniczenia górnej i dolnej Skawy wydaje się zatem zapora w Świnnej Porębie, której funkcjonowanie kształtować będzie warunki przepływu, a zatem również procesy geomorfologiczne.

Dolny bieg Skawy poniżej zapory w Świnnej Porębie, będący terenem analizy opisanej w niniejszym artykule, na całej długości 28 km nie jest jednorodny. Współczesna rzeźba doliny odzwierciedla budowę geologiczną północnego skłonu Karpat. Strukturalne i morfologiczne zróżnicowanie pozwala na wyodrębnienie czterech fragmentów dna doliny dolnej Skawy (ryc. 1).

Odcinek pierwszy (I) rozciąga się od mostu drogowego Świnna Poręba - Jaroszowice Gołębiówka, przekraczającego Skawę ok. 150 m poniżej niecki wypadowej przelewu powierzchniowego zapory w Świnnej Porębie, do progu piętrzącego wodę na potrzeby wadowickiego wodociągu. Stacja uzdatniania wody znajduje się u podnóża Goryczkowca (372 m n.p.m.), stanowiącego północną granicę Beskidu Małego. W tym odcinku dolina została wypreparowana w warstwach istebniańskich i godulskich serii śląskiej. Skały te budują zarówno znajdujący się na prawym brzegu masyw Jaroszowskiej Góry (544 m n.p.m.), jak i schodzące do doliny z lewej strony grzbiety grupy Leskowca (922 m n.p.m.). W północnej części odcinka I podnóże pasma Łysej Góry budują łupki cieszyńskie serii podśląskiej. Ten fragment doliny został uznany przez Mądrego (1970) za przełom strukturalny. Dno doliny osiąga szerokość 1200 m, rozszerzając się znacznie po przyjęciu lewobrzeżnej, górskiej Ponikiewki.

W drugim odcinku (II) dolina jest znacznie szersza. Wysokości bezwzględne tej części zlewni są niższe, a zbocza znacznie bardziej wypłaszczone. Pogórski charakter odcinka determinowany jest budową geologiczną. Płaty fliszu serii śląskiej i podśląskiej budują niewysokie garby, gdzie w okresie zlodowaceń akumulowane były miąższe kompleksy żwirów fluwialnych. Do rozszerzenia dna doliny przyczynił 


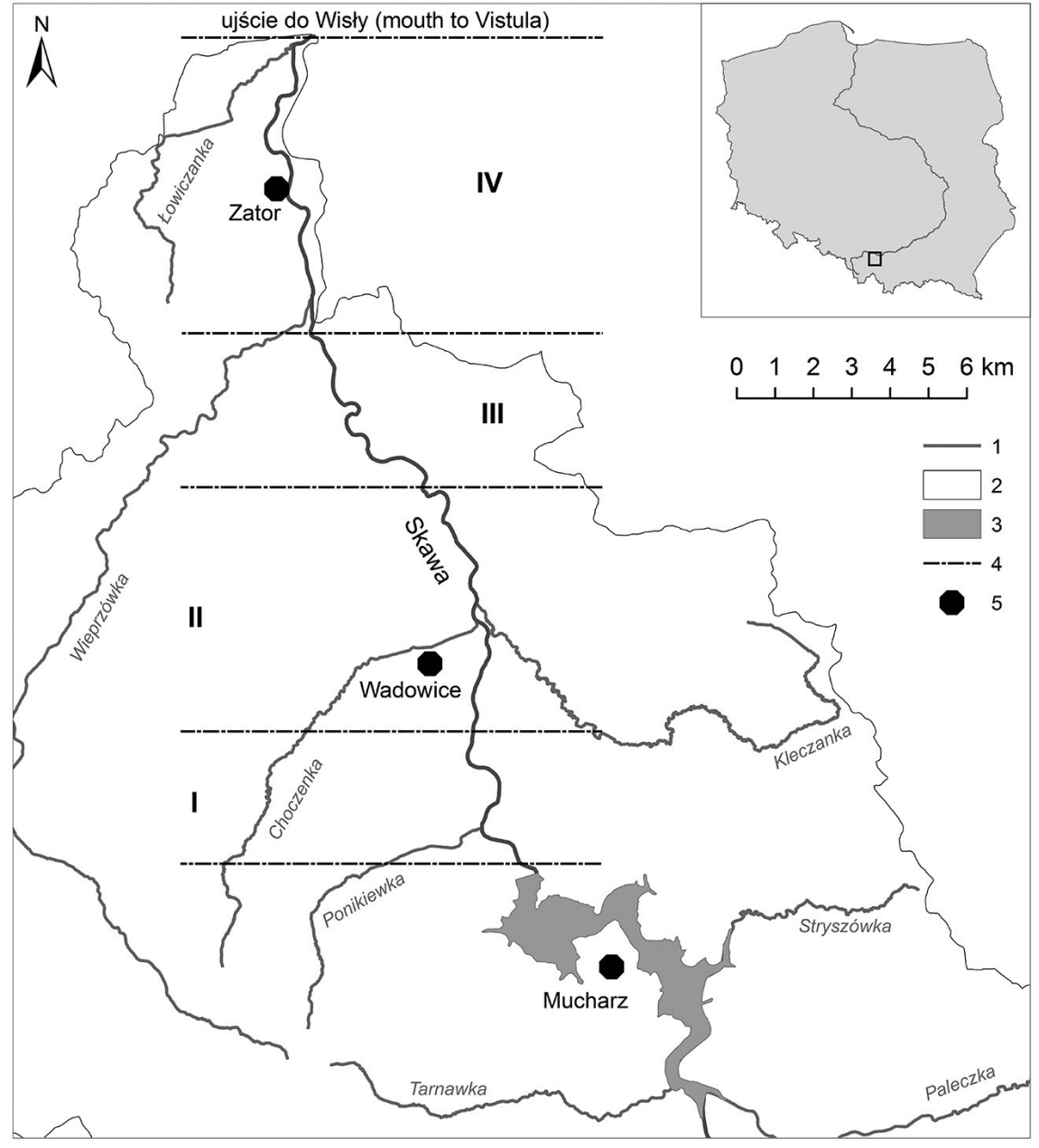

Ryc. 1. Teren badań

Fig. 1. Research area

Objaśnienia: 1 - cieki; 2 - zlewnia Skawy; 3 - zbiornik w Świnnej Porębie; 4 - granice odcinków badawczych; 5 - główne miejscowości; I, II, III, IV - numery odcinków badawczych

Explanations: 1 - rivers; 2 - Skawa catchment; 3 - Swinna Poreba Reservoir; 4 - boundaries sections; 5 - main cities; I, II, III, IV - numbers of sections

Źródto: opracowanie własne na podstawie serwisów WMS Geoportalu Infrastruktury Informacji Przestrzennej, http://geoportal.gov.pl (12.09.2016).

Source: authors own elaboration based on WMS National Geodetic and Cartographic Resources, http:// geoportal.gov.pl (12.09.2016). 
się lewobrzeżny dopływ Skawy - Choczenka. O jego wpływie na hydromorfologię Skawy świadczą rozmiary stożka napływowego usypanego w okresie zlodowaceń, na którym znajduje się centrum Wadowic (Klimaszewski 1948; Książkiewicz 1951). Szerokość dna doliny Skawy w II odcinku dochodzi do $2500 \mathrm{~m}$.

W miejscu, gdzie dolina ponownie się zwęża, rozpoczyna się odcinek III. Za przekrój rozgraniczający wybrano okolice ujścia prawobrzeżnego potoku Rędzina do Skawy. Za przewężenie doliny odpowiadają płaty serii śląskiej i podśląskiej o pogórskiej rzeźbie, pośród których przepływa Skawa. W najwęższym miejscu dolina dochodzi do $900 \mathrm{~m}$, w najszerszym do $1750 \mathrm{~m}$. Ten lokalny przełom, podobnie jak w całym pogórskim biegu Skawy, rozdziela Pogórze Śląskie i Wielickie. Skały fliszowego podłoża są przykryte warstwą żwirów fluwialnych sięgających wysokości nawet $25 \mathrm{~m}$ ponad współczesne dno doliny. W Woźnikach odnaleziono również ślady moreny lądolodu (Klimaszewski 1948).

Koniec odcinka III i początek IV przyjęto u zbiegu doliny Wieprzówki, największego pogórzańskiego dopływu Skawy, i doliny Skawy. Dno doliny zaczyna się tu rozszerzać za sprawą nagłego dopływu wód. Rozszerzeniu doliny sprzyja również skłon pogórza, gdzie wysokości względne są już stosunkowo nieznaczne. W odcinku IV znajduje się również fragment koryta położony na obszarze doliny Wisły. Tuż przed połączeniem się z doliną Wisły dolina Skawy osiąga szerokość 2500 m.

W dolinie dolnej Skawy Klimaszewski (1948) udokumentował położenie co najmniej trzech poziomów terasowych, których wiek wiązał z kolejnymi zlodowaceniami. Bober i in. (1980) wskazywali na istnienie czterech poziomów terasowych. Najwyżej położone żwiry rzeczne, 30 m ponad dnem doliny, zlokalizowano w górskim odcinku I dolnej Skawy.

\section{Cel i metody badań}

Celem artykułu jest określenie genezy, skali i kierunku przekształceń układu korytowego dolnej Skawy w XIX-XXI w. Określenie czynników transformacji XIX-wiecznego koryta wielonurtowego w XX-wieczne koryto jednonurtowe pozwoli na wskazanie genezy odcinkowej renaturyzacji współczesnego koryta. Współczesne brzegi Skawy na znacznej długości są zabezpieczone przed erozją, a przepływy wezbraniowe regulowane są przez zaporę w Świnnej Porębie. Otwarcie zbiornika wodnego, w zakresie projektowanej pojemności i przepustowości, umożliwi całoroczne kształtowanie przepływu. Dlatego zadaniem opracowania jest również wskazanie kierunków rozwoju koryta Skawy w warunkach współczesnej antropopresji.

W celu zobrazowania dawnego układu korytowego wykonano analizę kartograficzną materiału XIX-XXI-wiecznego. Badania kameralne wzbogacono o przegląd 
literatury technicznej traktującej o początkach regulacji koryt rzek galicyjskich. Analizy te uzupełniono wizjami terenowymi.

W pracy wykorzystano zróżnicowany materiał kartograficzny. Bazowym źródłem była mapa drugiego zdjęcia wojskowego Austro-Węgier z lat 1806-1869 (tzw. zdjęcia franciszkowskiego), wykonana na ziemiach Galicji przez kartografów austriackich w latach 1861-1864 (Affek 2013). Potwierdzona dokładność zobrazowania oraz digitalizacji (Vichrova 2012) zadecydowała o przyjęciu za podstawowe II zdjęcia kartograficznego, a nie starszego, tzw. mapy Miega. Na podstawie mapy franciszkowskiej dokonano pomiarów długości i szerokości koryta, form korytowych oraz doliny dolnej Skawy. W celu dokonania porównania współczesnego koryta z XIX-wiecznym pomiary powtórzono na zobrazowaniu satelitarnym Google Satellite wykonanym w 2012 r. Materiały przygotowano i opracowano w oprogramowaniu QGIS 2.6.1-Brighton. Mapę drugiego zdjęcia franciszkowskiego, z nadaną georeferencją, pozyskano ze zbiorów Zakładu Systemów Informacji Geograficznej, Kartografii i Teledetekcji Uniwersytetu Jagiellońskiego.

Wyniki pomiarów kartograficznych posłużyły za dane wejściowe do przeprowadzenia klasyfikacji układu korytowego oraz form śródkorytowych. Klasyfikację XIX i XXI-wiecznego koryta Skawy wykonano zgodnie z metodą Brice'a (1975). Rozwiązania zaproponowane przez Brice'a i ich modyfikacje zostały szeroko omówione przez Teisseyre'a (1991) oraz zmodyfikowane w celu dostosowania ich do analizy rzek sudeckich (Teisseyre 1992). Do analizy wykorzystano parametry zmodyfikowane przez Teisseyre'a (1991).

Metoda morfometryczna pozwala na zaklasyfikowanie koryta do określonego typu na podstawie pomiaru form śródkorytowych. W badaniach współczesnych koryt metoda ta jest niewystarczająca do poprawnego klasyfikowania form (Teisseyre 1991; Szmańda, Luc 2010). W przypadku zaś analiz historycznych układów koryt, których przebieg został odzwierciedlony na mapach, metoda ta jest jedną z nielicznych, które umożliwiają identyfikację koryta roztokowego lub anastomozującego. Ze względu na niedoskonałość metody jej wyniki potraktowano jako jeden z elementów dyskusji nad zmianą układu korytowego Skawy.

Zgodnie z metodą Brice'a (1975) przeanalizowano morfometrię form śródkorytowych. W tym celu dokonano pomiaru długości i szerokości form oraz łącznej szerokości nurtów je opływających. Dane metryczne przeliczono, by uzyskać wyniki parametrów bezwymiarowych, porównywalnych między różnymi układami korytowymi. Zgodnie z zaleceniami Brice'a i Blodgetta (1978) obliczono parametry bezwymiarowe:

- długości (długość formy/szerokość formy, L/w');

- szerokości (szerokość formy/łączna szerokość nurtów, w’/w).

W celu uzyskania bezwymiarowych parametrów kształtu i wielkości zastosowano obliczenia zaproponowane przez Szmańdę i Luc (2010). Bezwymiarowy parametr 
kształtu obliczano wg wzoru L/w' (długość formy/szerokość formy), a parametr wielkości - Lw' (długość formy x szerokość formy).

Parametry bezwymiarowe posłużyły jako kryteria klasyfikacji form śródkorytowych. Przyjęto, że odsypy śródkorytowe są formami koryta, które przy przepływach pełnokorytowych znajdują się pod wodą. W grupie tej znalazły się zarówno odsypy o powierzchni żwirowej, jak i odsypy pokryte roślinnością - kępy. Zgodnie z poglądami Teisseyre'a (1991) przyjęto, że obszary międzykorytowe to części dna doliny, które znajdują się pomiędzy korytami, zatem są morfometrycznym identyfikatorem anastomozowania. Każdorazowe użycie terminu „obszary międzykorytowe” odnosi się do form klasyfikowanych w analizie morfometrycznej, co ma szczególne znaczenie przy omówieniu wyników, gdyż część form uznano ostatecznie za roztokowe. Zastosowane przedziały kryteriów zestawiono w tab. 1.

Tab. 1. Kryteria klasyfikacji form korytowych oparte o parametry bezwymiarowe Table 1. Classification criteria of channel patterns based on non-dimensional parameters

\begin{tabular}{|c|c|c|c|c|c|c|}
\hline \multicolumn{7}{|c|}{$\begin{array}{l}\text { Kryteria klasyfikacji form wg Teisseyre'a (1991) * } \\
\text { Classification criterium of fluvial landform after Teisseyre (1991) * }\end{array}$} \\
\hline \multicolumn{7}{|c|}{$\begin{array}{l}\text { Klasyfikacja form wg wielkości } \\
\text { Classification of fluvial landform according to size }\end{array}$} \\
\hline \multirow{2}{*}{\multicolumn{2}{|c|}{$\begin{array}{l}\text { Odsypy śródkorytowe } \\
\text { Interchannel islands }\end{array}$}} & \multicolumn{5}{|c|}{$\begin{array}{l}\text { Odsypy śródkorytowe } \\
\text { Interchannel islands }\end{array}$} \\
\hline & & \multicolumn{2}{|c|}{$\begin{array}{l}\text { Krótkie } \\
\text { Short }\end{array}$} & $\begin{array}{l}\text { Wąskie } \\
\text { Narrow }\end{array}$ & $\begin{array}{l}\text { Długie } \\
\text { Long }\end{array}$ & $\begin{array}{l}\text { Szerokie } \\
\text { Broad }\end{array}$ \\
\hline $\mathrm{L} / \mathrm{W} \leq 4$ oraz & & \multicolumn{2}{|c|}{$4<\mathrm{L} / \mathrm{W} \leq 50$} & $w^{\prime} / w \leq 20$ & $\mathrm{~L} / \mathrm{W}>50$ & $w^{\prime} / w>20$ \\
\hline \multicolumn{7}{|c|}{$\begin{array}{l}\text { Kryteria klasyfikacji form wg Szmańdy i Luc (2010)* } \\
\text { Classification criterium of fluvial landform after Szmańda and Luc (2010)* }\end{array}$} \\
\hline \multicolumn{7}{|c|}{$\begin{array}{l}\text { Klasyfikacja form wg kształtu } \\
\text { Classification of fluvial landform according to shape }\end{array}$} \\
\hline \multicolumn{3}{|c|}{$\begin{array}{l}\text { Regularne } \\
\text { Regular }\end{array}$} & & $\begin{array}{l}\text { Wydłużone } \\
\text { Elongated }\end{array}$ & \multicolumn{2}{|c|}{$\begin{array}{l}\text { Liniowe } \\
\text { Linear }\end{array}$} \\
\hline \multicolumn{3}{|c|}{$\mathrm{L} / \mathrm{w}^{\prime} \leq 2$} & & $2<L / W^{\prime} \leq 10$ & \multicolumn{2}{|c|}{$L w^{\prime}>10$} \\
\hline \multicolumn{7}{|c|}{$\begin{array}{l}\text { Klasyfikacja form wg wielkości } \\
\text { Classification of fluvial landform according to size }\end{array}$} \\
\hline \multicolumn{4}{|c|}{$\begin{array}{l}\text { Odsypy śródkorytowe } \\
\text { Interchannel islands }\end{array}$} & \multicolumn{3}{|c|}{$\begin{array}{c}\text { Obszary międzykorytowe } \\
\text { Interchannel areas }\end{array}$} \\
\hline $\begin{array}{l}\text { Małe } \\
\text { Small }\end{array}$ & \multicolumn{2}{|c|}{$\begin{array}{l}\text { Średnie } \\
\text { Medium }\end{array}$} & $\begin{array}{l}\text { Duże } \\
\text { Large }\end{array}$ & $\begin{array}{l}\text { Małe } \\
\text { Small }\end{array}$ & $\begin{array}{r}\text { Średnie } \\
\text { Medium } \\
\end{array}$ & $\begin{array}{l}\text { Duże } \\
\text { Large }\end{array}$ \\
\hline$L w^{\prime} \leq 0,01$ & \multicolumn{2}{|c|}{$0,01<L w^{\prime} \leq 0,1$} & $L w^{\prime}>0,1$ & $L W^{\prime} \leq 1$ & $1<L w^{\prime} \leq 10$ & $L w^{\prime}>10$ \\
\hline
\end{tabular}

Objaśnienia / Explanations L - długość formy korytowej / fluvial landform length; w' - szerokość formy korytowej / fluvial landform width; w - łączna szerokość koryt / total width of channel.

* zmieniono terminologię / terminology changes. 


\section{Wyniki badań}

\section{Odcinek I}

W XIX wieku lokalny wpływ na procesy korytowe w odcinku I miała przede wszystkim Ponikiewka. Ciek ten odwadnia fragment beskidzkiego grzbietu - Gronia Jana Pawła II (890 m n.p.m.). Przed regulacją koryta (II poł. XX w.) Ponikiewka swobodnie transportowała dostarczaną ze stoków fliszową zwietrzelinę do Skawy. Ilość materiału dostarczana z gór znacznie przewyższała zdolności transportowe Skawy, co potwierdza obecność kilku odsypisk w pobliżu ujścia Ponikiewki. Dwa z nich, osiągając powierzchnię $0,11 \mathrm{~km}^{2}$ i $0,09 \mathrm{~km}^{2}$, według parametrów bezwymiarowych Teisseyre'a (1991) są obszarami międzykorytowymi, krótkimi i wąskimi. Zmodyfikowana klasyfikacja wg Szmańdy i Luc (2010) wskazuje, że formy te są wydłużone. Jeden z obszarów międzykorytowych $\left(0,11 \mathrm{~km}^{2}\right)$ znajdował się tuż powyżej ujścia Ponikiewki. Główny nurt opływał tę formę po wschodniej stronie. Obszar ten od zachodniego brzegu Skawy oddzielało wąskie boczne koryto, które było ujściowym odcinkiem potoku spływającego z Kozińca. Potok ten łączył się z wodami Skawy zarówno poprzez ujście (na północy), jak i od strony południowej przez kanał przelewowy Skawy. Obszar ten stanowił fragment terasy zalewowej, prawdopodobnie utrwalonej i być może użytkowanej rolniczo, na co wskazują szrafury na mapie franciszkowskiej. Niżej leżące dwa odsypy oraz obszar międzykorytowy mają powierzchnię pokrytą żwirami, co również potwierdza sposób prezentacji na mapie. Obszar międzykorytowy rozciąga się od ujścia Ponikiewki w dół rzeki. Lokalizacja form wskazuje, iż zostały one częściowo utworzone z materiału nanoszonego przez Ponikiewkę. Materiał był redeponowany na niewielkiej długości (ok. 1 km) koryta Skawy. Poniżej obszaru międzykorytowego znajdował się niewielki odsyp będący uprzednio częścią tego obszaru. Niespełna $0,5 \mathrm{~km}$ poniżej w korycie znajdował się kolejny niewielki $\left(0,005 \mathrm{~km}^{2}\right)$ odsyp zajmujący ponad $70 \%$ szerokości koryta. W pobliżu odsypu przeprawiano się przez Skawę brodem.

Współcześnie Skawa w odcinku I płynie w okresach relaksacji międzywezbraniowej korytem jednonurtowym. Odcinek ten rozpoczyna się poniżej niecki wypadowej zapory zbiornika Świnna Poręba. W korycie znajduje się kilka żwirowych odsypów bocznych. Interesujący jest środkowy fragment odcinka, gdzie znajduje się jedyne miejsce w dolnym biegu Skawy, gdzie koryto jest częściowo wycięte w litej skale. Skały podłoża odsłaniają się w prawym brzegu Skawy, u podnóża Jaroszowickiej Góry. Poniżej mostu drogowego w Jaroszowicach znajduje się obszar międzykorytowy (ryc. 2). Okresowo w jego pobliżu pojawiają się mniejsze formy śródkorytowe. Odsyp ten powstał w 2001 r., gdy w czasie wezbrania na skutek intensywnej erozji prawego brzegu w tym fragmencie koryta rozwinął się odcinek roztokowy. Odsyp był nadbudowywany w czasie kolejnych wezbrań oraz pokrywany roślinnością 


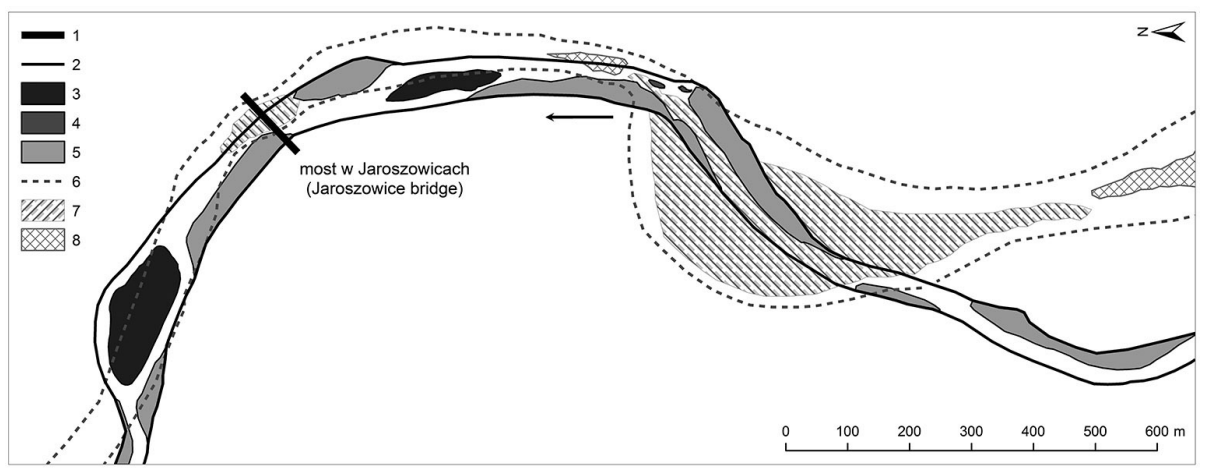

Ryc. 2. Szkic fragmentu I odcinka koryta dolnej Skawy

Fig. 2. Sketch of the Skawa river, a fragment of section I

Objaśnienia: 1 - most; 2 - brzegi w 2012 r.; 3 - obszary międzykorytowe w 2012; 4 - odsypy śródkorytowe w 2012; 5 - odsypy przybrzeżne w 2012; 6 - brzegi w 1869; 7 - obszary międzykorytowe w 1869; 8 - odsypy śródkorytowe w 1869.

Explanations: 1 - bridge; 2 - river banks in 2012; 3 - interchannel areas in 2012; 4 - central bars in 2012; 5 - point bars in 2012; 6 - river banks in 1869; 7 - interchannel areas in 1869; 8 - central bars in 1869 .

w okresach między wezbraniami. Najwyżej wyniesione części tej kępy w czasie wezbrania w 2014 r. znajdowały się ponad zwierciadłem wody. Koryto Skawy od okolic ujścia Ponikiewki do mostu drogowego w Jaroszowicach zostało w 2015 r. uregulowane. W wyniku prac powstało zabezpieczone przed erozją boczną i denną koryto jednonurtowe.

\section{Odcinek II}

Drugi odcinek badanego koryta już w XIX w. nie był znacznie urozmaicony. Pierwsze 6 km koryta było na przeważającej długości jednonurtowe. Udokumentowano na podstawie mapy istnienie 6 form śródkorytowych (3 odsypów i 3 obszarów międzykorytowych). Jeden z odsypów znajdował się pod mostem drogowym w Wadowicach, a jego powstanie wiązało się zapewne z depozycją w pobliżu przeszkody. Pomiędzy mostem a ujściem Choczenki znajdował się obszar międzykorytowy, genetycznie związany z zaburzeniami przepływu Skawy powodowanymi przez dopływ. Poniżej tego obszaru, w ujściu Choczenki kartografowie zaznaczyli zamiast form korytowych obszar podmokły. Brak dużych form żwirowych mógł być skutkiem ograniczenia dostawy rumowiska z Choczenki. Dopływ ten był bowiem przegrodzony w celu zasilania pobliskiego kompleksu stawów. Oznaczenie obszaru jako podmokłego 
mogło wynikać z obecności niskich, porośniętych odsypów, które wykorzystywane były jako przeprawy przez Skawę na drodze do Wadowic. Dwa kilometry poniżej ujścia Choczenki w rozszerzeniu koryta Skawy znajdowały się dwa odsypy śródkorytowe powstałe u podnóża skarpy jednego z pogórskich grzbietów. Brak w pobliżu choćby niewielkiego dopływu Skawy pozwala przypuszczać, że powstanie tych odsypów mogło być związane z erozją skarpy i dostawą dużej ilości materiału zwietrzelinowego z brzegu. Odcinek II zamykał drugi pod względem powierzchni w całej dolnej Skawie $\left(0,26 \mathrm{~km}^{2}\right)$ obszar międzykorytowy (ryc. 3) pokryty roślinnością. Kształt prawego koryta pozwala twierdzić, że forma ta zaczęła się rozwijać w obrębie zakola podcinającego strome w tym miejscu zbocza jednego z pogórskich grzbietów. Powyżej rozgałęzienia koryt Skawa przyjmowała Dopływ z Witanowic, a u ich zbiegu Radoczankę. Cieki te były zbyt małe, aby znacząco wpłynąć na rozwój obszaru międzykorytowego.

Współczesne koryto Skawy w odcinku II to efekt serii prac regulacyjnych, które doprowadziły do powstania jednonurtowej trasy regulacyjnej. Przebieg i geneza tej transformacji zostały opisane przez autora we wcześniejszej publikacji (Witkowski 2015b). We współczesnym korycie odcinka II występują głównie niewielkie odsypy

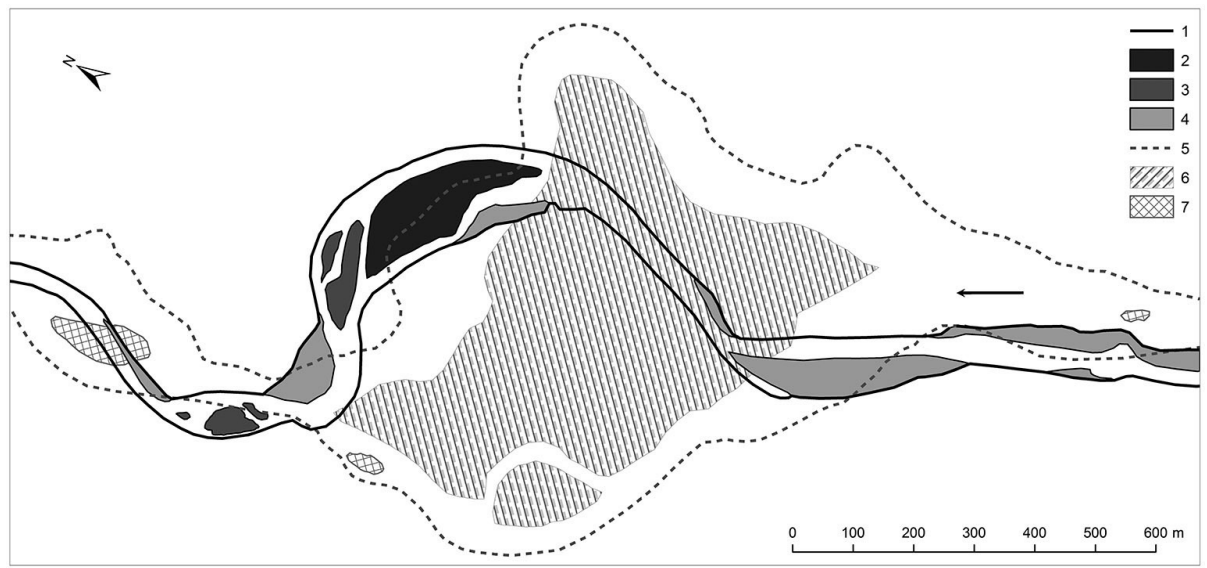

Ryc. 3. Szkic końcowego fragmentu II odcinka koryta dolnej Skawy

Fig. 3. Sketch of the Skawa river, a fragment of section II

Objaśnienia: 1 - brzegi w 2012 r.; 2 - obszary międzykorytowe w 2012; 3 - odsypy śródkorytowe w 2012; 4 - odsypy przybrzeżne w 2012; 5 - brzegi w 1869; 6 - obszary międzykorytowe w 1869; 7 - odsypy śródkorytowe w 1869.

Explanations: 1 - river banks in 2012; 2 - interchannel areas in 2012; 3 - central bars in 2012; 4 - point bars in 2012; 5 - river banks in 1869; 6 - interchannel areas in 1869; 7 - central bars in 1869 . 
boczne, zajmujące wypukłe brzegi zakoli. Pomiędzy mostami w Wadowicach, drogowym i kolejowym, od połowy XX w. znajduje się obszar międzykorytowy, który w trakcie kolejnych wezbrań został znacznie nadbudowany i tylko w czasie największych wezbrań jest w całości zatapiany. Powyżej ujścia Choczenki znajduje się trasa regulacyjna wybudowana w 2012 r. Główny nurt poprowadzony został pod prawym brzegiem. Pod lewym brzegiem znajduje się pozostawiony przez hydrotechników kanał odwadniający plac budowy, który podczas wezbrania w 2014 r. był wykorzystany przez Skawę jako trasa bocznego nurtu - w wyrównanym dnie pojawiły się wówczas strefy erozji i akumulacji. Pomiędzy nurtami znajduje się obszar międzykorytowy o powierzchni $0,03 \mathrm{~km}^{2}$, którego wschodnia część nosi jeszcze ślady prac regulacyjnych. Współczesna Choczenka, w wyniku uregulowania jej koryta, prawie w ogóle nie niesie rumowiska i w jej ujściu nie ma form akumulacyjnych. Między ujściem Choczenki a mostem drogowym w Witanowicach koryto Skawy tworzy seria zakoli uregulowanych na początku XXI w. Trasa regulacyjna jest tu ustabilizowana. Poniżej mostu w Witanowicach znajduje się najbardziej zdziczały odcinek koryta dolnej Skawy. Koryto wielonurtowe powstało u podnóża jednego z pogórskich grzbietów po zniszczeniu przez Skawę części narzutu z kamienia łamanego, ubezpieczającego prawy brzeg rzeki i ujście Dopływu z Zagórza. Na początku rozgałęzionego odcinka znajduje się obszar międzykorytowy, który w czasie niskich stanów wody jest połączony z lewym brzegiem. Niżej leżące dwa odsypy zostały w czasie kolejnych wezbrań połączone, tak że tylko w czasie utrzymywania się przepływów średnich i wysokich oddzielające je koryta prowadzą wodę. Północno-wschodni brzeg to wysokie podcięcie. Poniżej ujścia Radoczanki znajdują się dwa kolejne odsypy, które zajmują przeciwległe do poprzedniego zakole (ryc. 3). Pod wpływem dopływu w czasie mniejszych wezbrań na wypukłym brzegu zakola Skawy powstało aktywne podcięcie. Współczesna strefa erozyjna zamyka odcinek II koryta dolnej Skawy.

\section{Odcinek III}

Odcinek trzeci, zarówno historycznie, jak i współcześnie, nie jest urozmaicony. Koryto XIX-wieczne stanowiła seria różnopromiennych zakoli z odsypami bocznymi i pojedynczymi śródkorytowymi w rozszerzeniach koryta. W odcinku zidentyfikowano dwa obszary międzykorytowe, z których jeden pokryty był roślinnością. W początkowej części odcinka występowało starorzecze połączone ze Skawą od strony wody dolnej (ryc. 4).

Współcześnie w trzecim odcinku znajduje się kilka odsypów bocznych. W środkowej części odcinka znajdują się dwa zakola, których brzegi wklęsłe uległy znacznemu cofnięciu w 2010 r. Przy brzegach wypukłych występują odsypy boczne znacznych rozmiarów (po ok. $0,03 \mathrm{~km}^{2}$ ), z powierzchnią bogato urzeźbioną licznymi kanałami przelewowymi. 


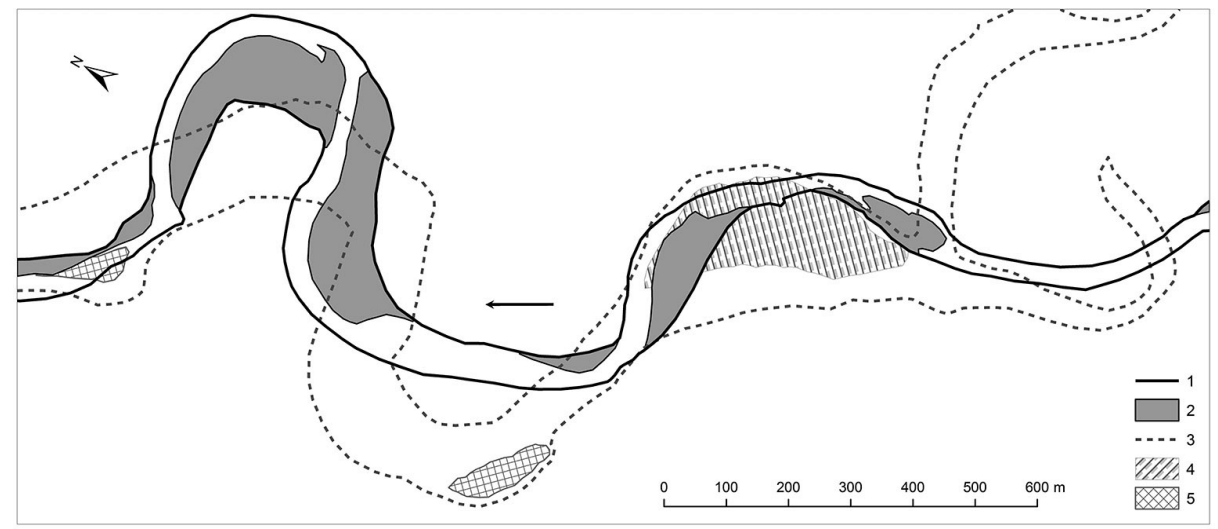

Ryc. 4. Szkic fragmentu III odcinka Skawy

Fig. 4. Sketch of the Skawa river, a fragment of section III

Objaśnienia: 1 - brzegi w 2012 r.; 2 - odsypy przybrzeżne w 2012; 3 - brzegi w 1869; 4 - obszary międzykorytowe w 1869; 5 - odsypy śródkorytowe w 1869.

Explanations: 1 - river banks in 2012; 2 - point bars in 2012; 3 - river banks in 1869; 4 -interchannel areas in $1869 ; 5$ - central bars in 1869 .

\section{Odcinek IV}

Odcinek IV rozpoczyna się u zbiegu dolin Wieprzówki i Skawy. XIX-wieczne koryto Skawy od tego miejsca znacznie się rozszerzało (do $800 \mathrm{~m}$ ), a w jego obrębie znajdowały się liczne formy śródkorytowe, łącznie 23 - najwięcej spośród wszystkich czterech odcinków. Oprócz Wieprzówki i Łowiczanki, której ujście do Skawy znajdowało się tuż przed jej ujściem do Wisły, na tym blisko 8-kilometrowym odcinku doliny nie znajdowały się żadne większe dopływy. Za bogactwo form odpowiadały zatem Skawa i Wieprzówka, łączące swe wody w wypłaszczeniu doliny Skawy, która ok. $3 \mathrm{~km}$ przed swym ujściem wpływała już do doliny Wisły. Na wysokości miasta Zator znajdował się największy na dolnej Skawie pokryty roślinnością obszar międzykorytowy, o powierzchni $0,47 \mathrm{~km}^{2}$ (ryc. 5), na którym znajdował się budynek. W rozdzielonych korytach znajdowały się liczne mniejsze obszary międzykorytowe oraz odsypy. Około 1,2 km dalej znajdował się drugi fragment rzeki z dużym obszarem międzykorytowym i towarzyszącymi mu mniejszymi formami. Te dwa fragmenty koryta Skawy oddzielał krótki odcinek jednonurtowy. W pobliżu ujścia do Wisły nurty Skawy rozdzielały się jeszcze w trzech miejscach. Na początku odcinka IV w pobliżu ujścia Wieprzówki znajdo- 


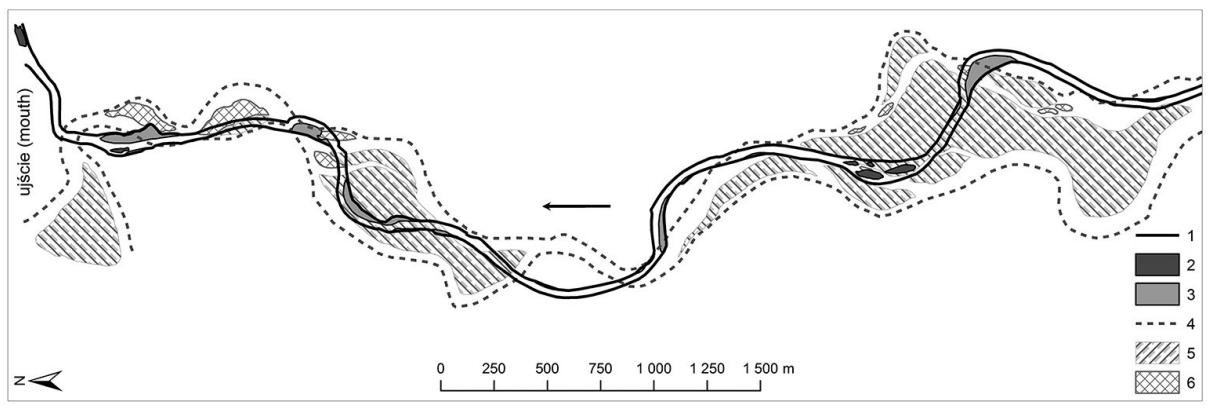

Ryc. 5. Szkic ujściowego odcinka Skawy stanowiącego fragment odcinka IV

Fig. 5. Sketch of the Skawa river mouth, a fragment of section IV

Objaśnienia: 1 - brzegi w 2012 r.; 2 - odsypy śródkorytowe w 2012; 3 - odsypy przybrzeżne w 2012; 4 - brzegi w 1869; 5 - obszary międzykorytowe w 1869; 6 - odsypy śródkorytowe w 1869.

Explanations: 1 - river banks in 2012; 2 - central bars in 2012; 3 - point bars in 2012; 4 - river banks in $1869 ; 5$ - interchannel areas in 1869; 6 - central bars in 1869 .

wało się znaczne rozszerzenie koryta Skawy - do 600 m, w którym pod wpływem dopływu utrzymywały się dwa duże obszary międzykorytowe, rozdzielone szerokim na ok. 120 m nurtem Skawy.

Współczesne koryto Skawy powyżej ujścia Wieprzówki przegrodzone jest jazem piętrzącym wody na potrzeby pobliskich stawów hodowlanych i ujęcia wody. $\mathrm{Na}$ ponad 3-kilometrowym odcinku koryta między jazem w Grodzisku a Zatorem nie występują żadne odsypy. W Zatorze znajduje się zakole, którego wklęsły brzeg jest aktywnie podcinany. Poniżej tego zakola znajduje się krótka trasa regulacyjna, w której obrębie pozostawiono odsypy śródkorytowe, których część utrzymała się w czasie późniejszych wezbrań. Poniżej mostów w Zatorze, drogowego i kolejowego, odnaleźć można kilka niewielkich odsypów bocznych. Tuż przed ujściem Skawy do Wisły, poniżej progu w Smolicach, w niewielkiej niszy erozyjnej lewego brzegu, znajduje się piaszczysty odsyp śródkorytowy. Próg w Smolicach reguluje transport rumowiska w Skawie, której ujście wykorzystane zostało jako dolny kanał wiślanej śluzy w Smolicach.

\section{Transformacja układu korytowego}

Transformacja układu korytowego Skawy została przeprowadzona przez człowieka na początku XX w. Motywacją do uregulowania rzeki i uporządkowania dna doliny były przede wszystkim plany budowy kanału galicyjskiego (Dunaj-Wisła-Dniestr), 
który miał być zasilany m.in. wodami Skawy. Tzw. rektyfikacja rzeki miała ograniczyć transport rumowiska oraz ustabilizować przepływy wezbraniowe. Ponadto regulacja miała ograniczyć migrację koryt, prowadzącą do niszczenia przybrzeżnych gruntów, zabezpieczyć przed zalewaniem i niszczeniem drogi biegnące wzdłuż rzeki oraz dostosować koryto do spławu drewna (Chlebowski 1889; Ingarden 1922; Witkowski 2015a).

Pierwsze prace ziemne, na dolnej Skawie, skracające i prostujące koryto, prowadzono już po powodzi w 1884 r. Główne działania regulacyjne zrealizowano, dzięki zagwarantowaniu pieniędzy przez ustawy sejmu galicyjskiego oraz sejmu centralnego w Wiedniu, w pierwszym dwudziestoleciu XX w. (Ingarden 1910). Przed II wojną światową całe koryto dolnej Skawy było już jednonurtowe (Witkowski 2015a).

Intensywne i kompleksowe prace regulacyjne przeprowadzone w stosunkowo krótkim czasie uniemożliwiają przeanalizowanie wpływu zmian użytkowania ziemi w zlewni na transformację układu koryta. XX-wieczny wzrost zalesienia w Karpatach oraz spadek udziału gruntów ornych w użytkowaniu ziemi (Kozak i in. 2007), przyczyniłby się do transformacji koryta Skawy przeprowadzonej przez człowieka (Wyżga i in. 2013).

Układ korytowy Skawy w okresie blisko 150 lat uległ znaczącej zmianie. W 1869 r. w każdym z 4 odcinków dolnej Skawy znajdowało się co najmniej 6 form śródkorytowych, a łącznie we wszystkich odcinkach - 45 (tab. 2). W 2012 r. w całym badanym biegu rzeki stwierdzono 19 form śródkorytowych, rozłożonych między 3 odcinki, z których tylko 5 jest obszarami międzykorytowymi. Wszystkie obszary są pokryte roślinnością.

Stosując klasyfikację form wg Brice'a (1975), zmodyfikowaną przez Teisseyre'a (1991), wszystkie formy śródkorytowe występujące w korytach z 1869 i 2012 r. sklasyfikowano jako odsypy śródkorytowe lub krótkie i wąskie obszary międzykorytowe (tab. 2). Nie stwierdzono istnienia długich $(\mathrm{L} / \mathrm{w}>50)$ i szerokich $(\mathrm{w} / \mathrm{w}>20)$ obszarów

Tab. 2. Charakterystyka form śródkorytowych występujących w dolinie Skawy w latach 1869 i 2012 (L - długość formy; w’ - szerokość formy; w - szerokość koryta)

Table 2. Description of mid-channel formations in the Skawa river valley in 1869-2012 ( $\mathrm{L}$ - length of form; w' - width of form; w - width of channel)

\begin{tabular}{|c|c|c|}
\hline $\begin{array}{l}\text { Koryto z roku } \\
\text { River bed in }\end{array}$ & $\begin{array}{l}\text { Odsypy śródkorytowe } \\
\left.\mathrm{L} / \mathrm{W} \leq 4 \text { ( } \mathrm{W}^{\prime} / \mathrm{w} \leq 1\right) \\
\text { Interchannel islands } \\
\mathrm{L} / \mathrm{w} \leq 4\left(\mathrm{w}^{\prime} / \mathrm{w} \leq 1\right)\end{array}$ & $\begin{array}{c}\text { Obszary międzykorytowe } \\
\text { Krótkie } 4<\mathrm{L} / \mathrm{w} \leq 50 \text { i wąskie w'/w } \leq 20 \\
\text { Interchannel areas } \\
\text { Short } 4<\mathrm{L} / \mathrm{w} \leq 50 \text { and narrow } \mathrm{w}^{\prime} / \mathrm{w} \leq 20\end{array}$ \\
\hline 1869 & 27 & 18 \\
\hline 2012 & 14 & 5 \\
\hline
\end{tabular}


międzykorytowych. Sumaryczna powierzchnia wszystkich form śródkorytowych w 1869 r. wynosiła 2,08 km², a w 2012 już tylko 0,1 km². Łączna długość brzegów Skawy, nie licząc brzegów form śródkorytowych, skróciła się z 59,9km (1869 r.) do $56,3 \mathrm{~km} w 2012 \mathrm{r}$.

\section{Dyskusja wyników}

XIX-wieczne koryto Skawy było bardzo urozmaicone, a liczba odcinków wielonurtowych pozwala nazywać układ korytowy dolnej Skawy z 1869 r. roztokowym, podobnie jak w przypadku wielu rzek karpackich (Wyżga i in. 2013; Gorczyca 2016). W świetle analizy morfometrycznej takie zaklasyfikowanie nie jest jednak jednoznaczne. Wielkość obszarów międzykorytowych wskazuje, że przynaje mniej na obszarze Kotliny Oświęcimskiej Skawa mogła być anastomozująca tak jak sudeckie rzeki w pogórskich odcinkach (Teisseyre 1991). Stawianie takich hipotez wymaga przeprowadzenia szczegółowych badań budowy dna doliny Skawy, ale w świetle poglądów Smitha i Smitha (1980), potwierdzonych badaniami Teisseyre'a (1991) w Sudetach czy Lehotský'ego i in. (2009), którzy udowodnili przekształcenie roztokowego koryta Dunaju w anastomozujące, nie jest bezpodstawne.

Zgodnie z opinią Teisseyre'a (1991) metoda morfometryczna nie jest wystarczająca do jednoznacznego zaklasyfikowania form śródkorytowych jako roztokowych lub anastomozujących. Badanie XIX-wiecznego koryta Skawa to potwierdza. Obszary międzykorytowe w odcinkach I-III znajdują się w dużych odległościach od siebie, a ich obecność można wiązać z działalnością dopływów Skawy lub lokalnymi zaburzeniami warunków przepływu i transportu osadów, które mogły być następstwem zróżnicowania odporności skał podłoża lub ruchów neotektonicznych, których wpływ na morfologię koryta górnej Skawy wykazali Jakubska (1987) i Grzybowski (1999). Największy obszar międzykorytowy był częściowo pokryty roślinnością, w tym drzewami, co pozwala sądzić, że forma ta była od dłuższego czasu ustabilizowana i mogła być już częścią równiny zalewowej, wyniesioną ponad koryto.

W XIX-wiecznym odcinku IV znajdowało się kilka dużych obszarów międzykorytowych, które wraz z odsypami śródkorytowymi tworzyły rozgałęziony układ koryt roztokowych. Zaklasyfikowanie tych obszarów jako część równiny zalewowej, co według Knightona i Nansona (1993) jest podstawowym wyznacznikiem anastomozowania, potwierdza:

- wielkość tych obszarów, największy - 0,47 km²;

- pokrycie części z nich roślinnością, m.in. drzewami;

- obecność zabudowań w obrębie największego obszaru międzykorytowego;

- liczba nurtów, dochodząca do 6, które mogłyby być uznane za koryta. 
Za uznaniem IV historycznego odcinka Skawy za anastomozujący przemawia również jego lokalizacja w obrębie doliny Wisły oraz brak górskich dopływów, dzięki czemu układ korytowy Skawy mógł rozwinąć się w piaszczysto-gliniastym podłożu (Książkiewicz 1951).

Według Gurnell i in. (2009) główną przyczyną zaniku koryt wielonurtowych jest bezpośrednia ingerencja człowieka w osady, m.in. poprzez pobór żwirów. Do zmiany układu korytowego Skawy doprowadzono natomiast poprzez uregulowanie jej korytaodcięcie bocznych nurtów, zawężenie i pogłębienie koryta oraz odseparowanie go od erodowanych brzegów. Podobne przyczyny zaniku wielonurtowości wskazano w przypadku Raby (Wyżga 1993), Dunajca (Zawiejska, Wyżga 2010), Sanu (Szumański 1986) i Soły (Woskowicz-Ślęzak, Ślęzak 2012). Ta ingerencja człowieka, trwająca począwszy od przełomu XIX i XX wieku do dziś, uniemożliwia odczytanie wpływu zmian użytkowania ziemi w zlewni na transformację układu korytowego. Przypuszczać można, że porzucanie gruntów ornych i ich stopniowe zarastanie, zwłaszcza w terenach górskich, przyczyniało się do utrwalania układu jednokorytowego stworzonego przez człowieka na początku XX w. (Wyżga i in. 2013).

Współczesna skłonność Skawy do roztokowania przejawia się wyraźnie w 5 fragmentach ponad 28-kilometrowego koryta. Miejsca te występują w pobliżu historycznych odcinków rozgałęzionych. W ich obrębie, w odcinkach I i II, znajdują się formy zaklasyfikowane w analizie morfometrycznej jako obszary międzykorytowe. Ze względu na pokrycie roślinnością formy te należy uznać za kępy, które w spągowej części zbudowane są z grubych żwirów. W czasie wezbrań formy te były nadbudowywane, przez co w stropowej części znajdują się zarówno żwiry, jak i piaski i mułki. Utrwaleniu śródkorytowych form pokrytych roślinnością oraz ich nadbudowie przez osady drobnoziarniste sprzyja przegłębianie koryta (Wyżga i in. 2016). Transformacja odsypów o powierzchni żwirowej w kępy, rozumiane za Jaroszewskim i in. (1985) jako wyspy utrwalone przez roślinność i wynurzone przy średnich stanach, a w konsekwencji dalszej nadbudowy i przegłębiania nurtów w formy wynurzone przy stanach wysokich może doprowadzić do utworzenia części równiny zalewowej w obrębie koryta. Proces ten może być odpowiedzią, na postulowane w literaturze (Petts i in. 1989) zerwanie łączności koryt rzek europejskich z terasami zalewowymi, prowadząc do wytworzenia nowego poziomu terasowego w obrębie rozszerzonych koryt roztokowych, które mogą w ten sposób przekształcić się w anastomozujące, co w przypadku Dunaju stwierdzili Lehotsky i in. (2009).

Za odrzuceniem jednoznacznego uznania Skawy za rzekę tylko roztokową i kontynuacją badań nad historycznym i współczesnym typem koryta Skawy przemawiają również poglądy Gorczycy (2016) potwierdzające, że współczesna samoczynna renaturyzacja koryt prowadzi do powstania układu korytowego dostosowanego do aktualnych warunków, ale nie odzwierciedlającego typu koryta sprzed regulacji. 


\section{Wnioski}

Działalność człowieka, szczególnie regulowanie rzek, na początku XX w. doprowadziła do zlikwidowania wielu roztokowych układów rzek karpackich, w tym rozgałęzionego koryta Skawy. Zmiana reżimu hydrologicznego oraz sposobu użytkowania ziemi w zlewniach miała wpływ na transformację układu korytowego Skawy, ale za sprawą działań hydrotechnicznych zmiany te są niezauważalne.

Współcześnie roztokowe odcinki koryta Skawy powstają m.in. w miejscach, gdzie dochodzi do zniszczenia umocnień brzegów. Poprzez erozję brzegów koryto zasilane jest rumowiskiem, które buduje formy śródkorytowe. Dalsza nadbudowa form śródkorytowych materiałem drobnoziarnistym prowadzi do podniesienia powierzchni odsypu i stworzenia warunków sprzyjających pojawieniu się roślinności. Nadbudowa kęp przy jednoczesnym pogłębianiu koryt może doprowadzić do wytworzenia się nowego poziomu terasowego w obrębie koryta. Taka transformacja skłania natomiast do rewizji poglądów na temat kierunków rozwoju koryta roztokowego Skawy.

Zastosowana w badaniach analiza morfometryczna wg Brice'a (1975), mimo swej niedoskonałości, może być narzędziem wspierającym w klasyfikowaniu form korytowych opartym na archiwalnych materiałach kartograficznych.

\section{Podziękowanie}

Dziękuję dr. hab. Jackowi Szmańdzie, prof UP, za udzielone wsparcie merytoryczne oraz anonimowym recenzentom za cenne uwagi do pierwszej wersji artykułu.

\section{Literatura}

Affek A., 2013, Georeferencing of historical maps using GIS, as exemplified by the Austrian Military Surveys of Galicia, Geographia Polonica, 86 (4), 375-390.

Bober L., Nowicka D., Wójcik A., 1980, Utwory czwartoræędowe w dolinie Skawy między Wadowicami a Zatorem, Rocznik Polskiego Towarzystwa Geologicznego, 50 (1), 119-137.

Brice J.C., 1975, Air photo interpretation in the form and behavior of alluvial river, Final Report for US Army Research Office.

Brice J.C., Blodgett J.C., 1978, Counter Measures for Hydraulic Problems at Bridges. 1. Analysis and Assessment, Report No. FHWA-RD-78-162. Fed. Highway Admin., Washington.

Chlebowski B., 1889, Stownik geograficzny Królestwa Polskiego i innych krajów stowiańskich, T. X, XII. Warszawa.

Gorczyca E., 2016, Rozwój górskich ¿̇wirodennych koryt rzecznych w warunkach antropopresji, Wydawnictwo IGiGP UJ, Kraków. 
Grzybowski K., 1999, Wptyw litologii i tektoniki serii fliszowych oraz mtodoczwartorzędowych ruchów tektonic:nych na uks:tattowanie doliny Skawy (zachodnie Karpaty zewnętræne), Przegląd Geologiczny, 47 (9), 846-850.

Gurnell A., Surian N., Zanoni L., 2009, Multi-thread river channels: A perspective on changing European alpine river systems, Aquatic Sciences, 71 (3), 253-265.

Ingarden R., 1910, Rozwój budownictwa wodnego w Galicyi w ostatniem dziesięcioleciu, Czasopismo Techniczne, 22, 23, 24.

Ingarden R., 1922, Rzeki i kanały żeglowne w træech zaborach $i$ znaczenie ich gospodarcze dla Polski, Kraków.

Jakubska O., 1987, Zwiqzek między elementami strukturalnymi ptaszczowiny magurskiej a morfologiq górnej czessci dorzecza Skawy, Czasopismo Geograficzne, 58 (1), 19-44.

Jaroszewski W., Marks L., Radomski A., 1985, Stownik geologii dynamicznej, Wydawnictwo Geologiczne, Warszawa.

Klimaszewski M., 1948, Polskie Karpaty Zachodnie w okresie dyluwialnym, Prace Wrocławskiego Towarzystwa Naukowego, Seria B, 7.

Klimek K., 1987, Man's Impact on Fluvial Processes in the Polish Western Carpathians, Geografiska Annaler. Series A, Physical Geography, 69 (1), 221-226.

Knighton A.D., Nanson G.C., 1993, Anastomosis and the continuum of channel pattern, Earth Surface Processes and Landforms, 18 (7), 613-625.

Kozak J., Estreguil C., Troll M., 2007, Forest cover changes in the northern Carpathians in the $20^{\text {th }}$ century: a slow transition, Journal of Land Use Science, 2, 127-146.

Książkiewicz M., 1951, Ogólna Mapa Geologiczna Polski w skali 1:50 000, Arkusz Wadowice, Państwowy Instytut Geologiczny, Warszawa.

Lach J., Wyżga B., 2002, Channel Incision and Flow Increase of the Upper Wistoka River, Southern Poland, Subsequent to the Reforestation of its Catchment, Earth Surface Processes and Landforms 27 (4), 445-462.

Lehotský M., Novotný J., Szmańda J.B., Grešková A., 2010, A suburban inter-dike river reach of a large river: Modern morphological and sedimentary changes (the Bratislava reach of the Damube River, Slovakia), Geomorphology, 117 (3-4), 298-308.

Mądry J., 1970, Próba odtworzenia genezy przetomów Skawy præez Beskid Mały, Prace Geograficzne, 5 (40), 35-41.

Petts G.E., Moller H., Roux A.L., (red.), 1989, Historical change of large alluvial rivers: Western Europe, Wiley, Chichester.

Smith D.G., Smith N.D., 1980, Sedimentation in anastomosed river system: example from alluvial valley Near Banff, Alberta, Journal of Sedimentary Research, 50 (1), 157-164.

Szmańda J.B., Luc M., 2010, Uktad wielokorytowy Dunaju pomiędzy Ćunovem a Gabćikovem - analiæa præestræenna na podstawie klasyfikacji ræek wedtug Brice'a, Landform Analysis, 13, 129-133.

Szumański A., 1986, Postglacjalna ewolucja i mechanizm transformacji dna doliny dolnego Sanu, Geologia, 12, 5-92. 
Teisseyre A.K., 1991, Klasyfikacja rzek w swietle analizy systemu fluwialnego i geometrii hydraulicznej, Prace Geologiczno-Mineralogiczne, 22, Wydawnictwo Uniwersytetu Wrocławskiego, Wrocław.

Teisseyre A.K., 1992, Rzeki anastomozujace - procesy i model sedymentacji, Przegląd Geologiczny, $4,241-248$.

Vichrova M., 2012, Digital terrain model of the Second Military Survey. Two model territories: the surroundings of the town Rokycany and part of the military training area Brdy, E-Perimetron, 7 (3), 124-135.

Witkowski K., 2015a, Ewolucja koryta dolnej Skawy w swietle zabudowy hydrotechnicะnej, Acta Scientiarum Polonorum Formatio Circumiectus, 14 (1), 213-221.

Witkowski K., 2015b, Funkcjonowanie sabezpieczonego koryta Skawy w Wadowicach, Gospodarka Wodna, 8, 230-233.

Woskowicz-Ślęzak B., Ślęzak A., 2012, Zapis antropopresji w ræe̋́bie præedgórskiej odcinka dna doliny Soty, [w:] A. Łajczak, I. Malik (red.), Antropopresja w wybranych strefach morfoklimatycænych - sapis zmian w ræébie i osadach, Prace Wydziału Nauk o Ziemi Uniwersytetu Śląskiego 77, 441-452.

Wyżga B., 1993, Funkcjonowanie systemu rzecznego środkowej i dolnej Raby w ostatnich 200 latach, Dokumentacja Geograficzna, 6, 1-92.

Wyżga B., Zawiejska J., Hajdukiewicz H., 2013, Uwarunkowania wystepowania i przyczyny zaniku wielonurtowej morfologii rzek polskich Karpat, [w:] B. Wyżga (red.), Stan środowiska rzek potudniowej Polski - znaczenie środowiskowe, degradacja i mo:̇liwości rewitalizacji rzek wielonurtowych, Instytut Ochrony Przyrody PAN, Kraków, 7-32.

Wyżga B., Zawiejska J., Radecki-Pawlik A., 2016, Impact of channel incision on the hydraulics of flood flows: Examples from Polish Carpathian rivers, Geomorphology, 272, 10-20.

Zawiejska J., Wyżga B., 2010, Twentieth-century Channel Change on the Dunajec River, Southern Poland: Patterns, Causes and Controls, Geomorphology, 117 (3), 234-246.

Zwoliński Z., 1992, Sedimentology and geomorphology of overbank flows on meandering river floodplains, Geomorphology, 4, 367-379.

\title{
Strony internetowe
}

Geoportal Infrastruktury Informacji Przestrzennej, http://geoportal.gov.pl (2.09.2016).

Charakterystyka obszaru działania, http://oki.krakow.rzgw.gov.pl (12.08.2016).

\author{
Karol Witkoweski \\ Uniwersytet Pedagogiczny w Krakowie \\ Instytut Geografii \\ ul. Podchorqzisch 2, 30-084 Kraków \\ witkowski@up.krakow.pl
}


